$10 \mid 2006$

Varia

\title{
Les figures du musicien au Moyen Âge : images et discours
}

Centre d'études médiévales d'Auxerre, 24-25 mai 2007

\section{Martine Clouzot}

\section{(2) OpenEdition}

\section{Journals}

Édition électronique

URL : https://journals.openedition.org/cem/395

DOI : 10.4000/cem.395

ISSN : 1954-3093

Éditeur

Centre d'études médiévales Saint-Germain d'Auxerre

Édition imprimée

Date de publication : 15 août 2006

ISSN : 1623-5770

\section{Référence électronique}

Martine Clouzot, «Les figures du musicien au Moyen Âge : images et discours », Bulletin du centre d'études médiévales d'Auxerre | BUCEMA [En ligne], 10 | 2006, mis en ligne le 08 septembre 2006, consulté le 22 septembre 2022. URL : http://journals.openedition.org/cem/395 ; DOI : https://doi.org/ 10.4000/cem.395

Ce document a été généré automatiquement le 22 septembre 2022.

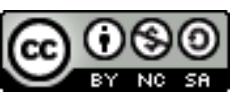

Creative Commons - Attribution - Pas d'Utilisation Commerciale - Partage dans les Mêmes Conditions 4.0 International - CC BY-NC-SA 4.0

https://creativecommons.org/licenses/by-nc-sa/4.0/ 


\section{Les figures du musicien au Moyen Âge : images et discours}

Centre d'études médiévales d'Auxerre, 24-25 mai 2007

Martine Clouzot

1 «Musicien»: le mot lui-même n'existe pas dans les textes en langue romane. En revanche, beaucoup de personnages nommés musicus, cantor, cantatrix, tibicines, joculatores, histriones, et joueurs d'instruments, ménestrels, jongleurs, chantres, harpistes, etc., circulent dans les sources latines et en langue vernaculaire. D'autres encore sont insérés dans les images sous les traits du berger, du roi David, de l'ange, du diablotin, de l'animal, du monstre, du poète... La complexité et le caractère protéiforme $\mathrm{du}$ « musicien » appellent alors à l'interroger sous l'angle de la «figure » - de discours et iconographique.

2 L'idée de cette rencontre est de réunir des historiens, des historiens de l'art, de la littérature, de la musique et des musicologues autour du «musicien» au Moyen Âge. Les sources spécifiques à chaque discipline apporteront des éléments de définition et d'interprétation du "musicien ». En effet, l'étude des vocables et des différents sens qu'ils recouvrent selon les périodes, les textes et les contextes, sera à la base de la réflexion proposée. De même, l'observation des formes iconographiques, des thématiques, des supports visuels permettra de proposer une typologie du musicien en rapport avec les milieux d'élaboration, les commanditaires et les usages des objets et des images. La confrontation des textes et des images donnera ainsi toute leur importance aux questions méthodologiques propres à chaque source et à chaque discipline.

Deux problématiques sous-tendront cette table ronde sur le «musicien ». D'une part, on s'interrogera sur les rapports entre les figures de discours et leurs implications sociales. D'autre part, les "figures du musicien" présentant le grand intérêt de dépasser l'étude du «musicien » en tant que tel, nous verrons en quoi et à quelles fins elles servent les discours spéculatifs sur le monde créé par Dieu et sur la place de l'homme dans l'univers divin. 
4 La formule de cet atelier se veut conviviale et ne vise pas à présenter une recherche aboutie, mais à réfléchir ensemble sur les travaux en cours qui croisent de près ou de loin des figures du musicien. La participation de Jean-Marie FRITZ (professeur de littérature médiévale à l'université de Bourgogne), de Silvere MENEGALDo (maître de conférences en littérature médiévale à l'université d'Orléans), d'Étienne ANHEIM (École française de Rome), d'Eduardo AUBERT (doctorant à l'université de São Paulo) est d'ores et déjà à retenir.

INDEX

Mots-clés : musicien 